\title{
Mechanism of the protective effects of the combined treatment with rhynchophylla total alkaloids and sinapine thiocyanate against a prothrombotic state caused by vascular endothelial cell inflammatory damage
}

\author{
YUNLUN LI ${ }^{1 *}$, XINYA ZHANG ${ }^{2 *}$, WENQING YANG ${ }^{2}, \mathrm{CHAO} \mathrm{LI}^{2}$, \\ YANJUN CHU ${ }^{2}$, HAIQIANG JIANG ${ }^{2}$ and ZHENZHEN SHEN ${ }^{2}$ \\ ${ }^{1}$ Department of Cardiology, Affiliated Hospital of Shandong University of \\ Traditional Chinese Medicine, Jinan, Shandong 250014; ${ }^{2}$ First Clinical Medical College, \\ Shandong University of Traditional Chinese Medicine, Jinan, Shandong 250000, P.R. China
}

Received September 15, 2015; Accepted January 26, 2017

DOI: $10.3892 / \mathrm{etm} .2017 .4357$

\begin{abstract}
The aim of the present study was to investigate the effect and the underlying mechanism of the combined treatment of rhynchophylla total alkaloids (RTA) and sinapine thiocyanate for protection against a prothrombotic state (PTS) associated with the tumor necrosis factor-alpha (TNF- $\alpha$ )-induced inflammatory injury of vascular endothelial cells (VECs). A TNF- $\alpha$-induced VEC inflammatory injury model was established, and cell morphology of VECs was evaluated using scanning electron microscopy. In addition, reverse transcription-quantitative polymerase chain reaction and western blot analysis were performed to examine the mRNA and protein expression of coagulation-related factors, including nuclear factor- $\kappa \mathrm{B}(\mathrm{NF}-\mathrm{\kappa} \mathrm{B})$, transforming growth factor- $\beta 1$ (TGF- $\beta 1)$, tissue factor (TF), plasminogen activator inhibitor (PAI-1), protease-activation receptors (PAR-1) and protein kinase C (PKC- $\alpha$ ) in VECs. Combined treatment with
\end{abstract}

Correspondence to: Professor Yunlun Li, Department of Cardiology, Affiliated Hospital of Shandong University of Traditional Chinese Medicine, 16369 Jingshi Road, Jinan, Shandong 250014, P.R. China

E-mail: yunlun.lee@hotmail.com

${ }^{*}$ Contributed equally

Abbreviations: RTA, rhynchophylla total alkaloids; VECs, vascular endothelial cells; SEM, scanning electron microscopy; NF- $\kappa \mathrm{B}$, nuclear factor- $\kappa \mathrm{B}$; TGF- $\beta 1$, transforming growth factor- $\beta 1$; TF, tissue factor; PAI-1, plasminogen activator inhibitor; PAR-1, protease-activation receptors; PKC- $\alpha$, protein kinase C; PTS, prothrombotic state; PCR, polymerase chain reaction

Key words: rhynchophylla total alkaloids, sinapine thiocyanate, vascular endothelial cells, inflammatory damage, prothrombotic state
RTA and sinapine thiocyanate was demonstrated to reduce, to a varying extent, the mRNA and protein expression of NF- $\kappa$ B, TGF- $\beta 1$, TF, PAR-1, PKC- $\alpha$ and PAI-1. Furthermore, combined treatment with RTA and sinapine thiocyanate was able to downregulate the expression of coagulation-related factors in injured VECs, thereby inhibiting the PTS induced by vascular endothelial injury. The underlying mechanism is partially associated with the TF-mediated activation of the thrombin-receptor signaling pathway that suppresses coagulation during inflammation and balances fibrinolysis in order to inhibit fibrin generation and deposition.

\section{Introduction}

Prothrombotic state (PTS) is a condition in which there is a tendency for thrombosis in the body. A previous study reported that PTS is closely associated with target-organ damage during hypertension (1). Vascular endothelial injury occurring during hypertension is the initiating factor for the development of atherosclerosis and thrombosis (2). Extensive crosstalk occurs between vascular endothelial injury, inflammation, and the coagulation/fibrinolytic system, and the impairment of endothelial function during inflammation is the primary cause for enhanced coagulation (3). Vascular endothelial injury may, to a varying extent, reduce or impair the functions of endothelial cells in regulating coagulation and anticoagulation as well as fibrin generation and fibrinolysis, leading to hypercoagulability of the blood, development of pathological thrombosis, and thereby, inducing thromboembolic disease. Therefore, protecting endothelial cells from injury, enhancing the roles of endothelial cells in anticoagulation and anti-thrombosis, and reversing the PTS are of great importance in preventing the occurrence and progression of thrombosis or thromboembolic disease.

Uncaria is a medicinal herb typically used in traditional Chinese medicine for the treatment of hypertension, and its active components are the Uncaria rhynchophylla total alkaloids (RTA). Modern pharmacological studies have 
demonstrated that RTA exerts a variety of pharmacological effects, including reducing blood pressure and anti-arrhythmia, protecting against cerebral hypoxia and ischemia, inhibiting platelet aggregation and thrombosis, improving vascular remodeling, antagonizing the senescence of vascular endothelial cells (VECs), as well as sedative and antiepileptic effects on the central nervous system (4-6). Raphani semen is the dried ripe seed of Raphanus sativus L. Recent studies have shown that Raphani semen exhibits a strong antihypertensive effect and its active component is sinapine thiocyanate (7). It was previously demonstrated that combined treatment with RTA and sinapine thiocyanate shows antihypertensive and protective effects on vascular endothelia. Furthermore, the underlying mechanism is associated with inhibition of the secretion of adhesion molecules by VECs and alleviates inflammatory reactions in the vascular wall (7).

However, whether combined treatment with RTA and sinapine thiocyanate is able to affect coagulation-related factors and inhibit the occurrence of a procoagulant state in vascular endothelial injury remains to be clarified and the underlying mechanisms are unclear. To this end, a model for VEC injury induced by tumor necrosis factor- $\alpha$ (TNF- $\alpha$ ) was established and indicators were selected for endothelial coagulation/fibrinolysis. VECs treated with valsartan, which exerts an antihypertensive and protective effect on VECs (8), were used as a positive control. Either RTA, sinapine thiocyanate or a combination of the two was used to treat VECs. Following treatment, the cell morphology of VECs injured by TNF- $\alpha$-induced inflammation was examined and the expression levels of mRNA and proteins of multiple genes were analyzed, including nuclear factor- $\kappa \mathrm{B}(\mathrm{NF}-\kappa \mathrm{B})$, transforming growth factor- $\beta 1$ (TGF- $\beta 1$ ), tissue factor (TF), plasminogen activator inhibitor (PAI-1), protease-activation receptors (PAR-1) and protein kinase C- $\alpha$ (PKC- $\alpha)$. The aim of the present study was to investigate the effect of combined treatment with RTA and sinapine thiocyanate in the protection against the procoagulant state during TNF- $\alpha$-induced VEC injury, and to elucidate its underlying mechanism.

\section{Materials and methods}

Cell culture. Ethical approval for the present study was obtained from the Faculty of Medicine and Health Sciences Ethics Committee for Animal Research, Affiliated Hospital of Shandong University of Traditional Chinese Medicine (Jinan, China), and all efforts were made to minimize the potential for pain and distress in animals. VECs were obtained from the thoracic aorta of 12 male suckling mice, which were 3-7 days old and weighed $10 \mathrm{~g}$ (purchased from the Animal Experiment Center of Shandong University of Traditional Chinese Medicine). The mice were housed at $22 \pm 1^{\circ} \mathrm{C}$, under $60 \%$ humidity and a 12-h light/dark cycle. Purified water and food was supplied by the Animal Experiment Center of Shandong University of Traditional Chinese Medicine. The suckling mice were anesthetized with $10 \%$ chloral hydrate (cat. no. 302-17-0; Yangzhou Aoxin Chemical Factory, Yangzhou, China) $(0.03 \mathrm{ml} / 10 \mathrm{~g})$ and the thoracic aorta was extracted. The thoracic aorta was rinsed in sterile PBS repeatedly, cut into $1 \mathrm{~mm}^{3}$ pieces (without any fixing agents or preservatives) and inoculated evenly into the culture flask.
VECs were cultured using a tissue-sticking method in DMEM/F12 medium (Gibco; Thermo Fisher Scientific, Inc., Waltham, MA, USA) containing $10 \%$ fetal bovine serum (Hangzhou Sijiqing Biological Engineering Materials Co., Ltd., Hangzhou, China) at $37^{\circ} \mathrm{C}$ in an atmosphere containing $5 \% \mathrm{CO}_{2}$ in a humidified incubator. VECs were subcultured using a trypsin digestion method when they covered $>80 \%$ of the bottom of the culture bottle. The primary cells were passaged in a ratio of 1:2 or 1:3, and cells from the 4th to 6th generation were used for the study. The suckling mice were euthanized by overdose anesthesia with sodium pentobarbital (Sigma-Aldrich; Merck KGaA, Darmstadt, Germany) (60 mg/kg, intravenously) and exsanguination following tissue collection.

Treatment. Based on a previous study by the present authors (9), the optimal concentrations for TNF- $\alpha$, dimethylsulfoxide (DMSO), valsartan, RTA and sinapine thiocyanate, were $5 \mu \mathrm{g} / \mathrm{l}, 0.8 \mathrm{ml} / 1,80 \mathrm{mg} / 1,100 \mathrm{mg} / \mathrm{l}$ and $60 \mathrm{mg} / \mathrm{l}$, respectively. Following cell attachment, VECs were incubated with TNF- $\alpha$ (Cell Signaling Technology, Inc., Danvers, MA, USA) and $\mathrm{DMEM} / \mathrm{F} 12$ medium at $37^{\circ} \mathrm{C}$ for $6 \mathrm{~h}$ to form models for inflammation, and then preincubated for $48 \mathrm{~h}$ and synchronized using the serum hunger method (cells were cultured without serum) for $24 \mathrm{~h}$. The VECs obtained were divided into 7 groups ( $\sim 10^{6}$ cells/group): i) Normal control (without special treatment); ii) DMSO (exposed to 0.1\% DMSO and DMEM/F12); iii) TNF- $\alpha$ (treated with $3 \mathrm{ng} / \mathrm{ml} \mathrm{TNF}-\alpha$ ); iv) valsartan (treated with $80 \mathrm{mg} / \mathrm{l}$ valsartan); v) RTA (treated with $200 \mathrm{mg} / \mathrm{l} \mathrm{RTA}$ ); vi) sinapine thiocyanate (treated with $15 \mathrm{mg} / \mathrm{l}$ sinapine thiocyanate); and vii) RTA and sinapine thiocyanate (treated with $100 \mathrm{mg} / \mathrm{l} \mathrm{RTA}$ and $15 \mathrm{mg} / \mathrm{l}$ sinapine thiocyanate) group. Each group, except the normal control, was initially incubated with $3 \mathrm{ng} / \mathrm{ml} \mathrm{TNF}-\alpha$ for $6 \mathrm{~h}$ to induce the inflammation process and was subsequently treated with the aforementioned agents for a further $48 \mathrm{~h}$ prior to analysis.

Observation of cell morphology. The morphology of VECs was observed using a scanning electron microscope (SEM) as follows: i) The treated cells were fixed in $2.5 \%$ glutaraldehyde solution for $24 \mathrm{~h}$; ii) following fixation, cells were washed in $1.2 \mathrm{~mol} / \mathrm{l}$ phosphate buffer, which was changed thrice within $3 \mathrm{~h}$; iii) cells were subsequently fixed in $1 \%$ osmic acid for 1-1.5 $\mathrm{h}$ and washed in double-distilled water, which was replaced thrice in $2 \mathrm{~h}$; iv) cells were dehydrated twice at room temperature, using 50, 70, 80, 90 and $100 \%$ ethanol, for $20 \mathrm{~min}$ at each concentration; $v$ ) the ethanol solution was replaced with isoamyl acetate; cells were placed in a critical point drying apparatus (a high-pressure hermetically sealed container) and liquid carbon dioxide was added. The cells were then dried at a critical temperature of $31.8^{\circ} \mathrm{C}$ and 72.8 atm, sputter-coated with platinum using an IB-5 sputter coater and observed using an SEM and photographed.

Reverse transcription-quantitative polymerase chain reaction (RT-qPCR). TRIzol reagent kits (Invitrogen; Thermo Fisher Scientific, Inc.) were used to extract total RNA and reverse transcription kits (TIANScript RT Kit; Beijing Tiangen Biotech Co., Ltd., Beijing, China) were used to produce cDNA. A LightCycler 480 detection system (Roche Diagnostics, 
Indianopolis, IN, USA) was used for qPCR with qPCR kits (Light Cycler 480 SYBR-Green I Master; Roche Diagnostics, Indianapolis, IN, USA) with each sample in triplicate $\left(95^{\circ} \mathrm{C}\right.$ for $35 \mathrm{sec}$ and $60^{\circ} \mathrm{C}$ for $31 \mathrm{sec}$, followed by 40 cycles; $95^{\circ} \mathrm{C}$ for $15 \mathrm{sec}, 60^{\circ} \mathrm{C}$ for $60 \mathrm{sec}$ and $95^{\circ} \mathrm{C}$ for $15 \mathrm{sec}$.). PCR primers used were as follows: NF- $\mathrm{B}$ : 5'-TGGGACGACACCTCT ACACA-3' (forward) and 5'-GGCTCAAAGTTCTCCACC AG-3' (reverse); TF: 5'-AGAGCCCAGAAAGCATCA CCAAG-3' (forward) and 5'-AGCCTCCTCGTCTATGCC AAGC-3' (reverse); TGF- $\beta 1$ : 5'-CATTGCTGTCCCGTG CAGA-3' (forward) and 5'-AGGTAACGCCAGGAATTG TTGCTA-3' (reverse); PAR-1: 5'-CCTATGAGACAGCCA GAATC-3' (forward) and 5'-GCTTCTTGACCTTCATCC-3' (reverse); PKC- $\alpha$ : 5'-GCTCTACGGACTTATCCACCA-3' (forward) and 5'-TCTGTGACCTCTGCC TTC AG-3' (reverse); PAI-1: 5'-AGGCCCCAGCAGAGTGGAGG-3' (forward) and 5'-GGCGATGCAAGAGGTGCCCA-3' (reverse); $\beta$-actin: 5'-CGTTGACATCCGTAAAGA-3' (forward) and 5'-AGCCACCATCCACACAG-3' (reverse). Results were analyzed using the $2^{-\Delta \Delta \mathrm{Cq}}$ method (10). Relative expression was normalized against that of $\beta$-actin.

Western blot analysis. The cell lysate was prepared using radioimmunoprecipitation lysis buffer (Beijing Solarbio Science \& Technology Co., Ltd., Beijing, China) and enzyme inhibitor $4: 1$. The cells were centrifuged at $8,900 \times \mathrm{g}$ at $4{ }^{\circ} \mathrm{C}$ for $30 \mathrm{~min}$, and the supernatant was stored at $-80^{\circ} \mathrm{C}$. Protein concentrations were measured using a bicinchoninic acid assay kit (Beyotime Institute of Biotechnology, Haimen, China). Protein samples (40 $\mu \mathrm{g}$ total) were separated by SDS-PAGE (12\%) and then transferred onto polyvinylidene fluoride membranes (EMD Millipore, Billerica, MA, USA). The membranes were placed in 5\% skimmed milk with appropriate primary antibodies and incubated overnight at $4^{\circ} \mathrm{C}$. Subsequently, horseradish peroxidase-conjugated secondary antibodies (Beijing Zhongshan Golden Bridge Biotechnology Co., Ltd., Beijing, China) were added and incubated at room temperature for $1 \mathrm{~h}$. An equivalent volume mixture of Immobilon Western (EMD Millipore) was added to the membranes, which were then photographed using a LAS-4000 imager. Image-Pro Plus 4.5 software (Media Cybernetics, Inc., Silver Spring, MD, USA) was used for semi-quantitative image analysis and integrated optical density determination, where the average density was considered as the expression level of the protein. The primary antibodies used were anti- $\beta$-actin (bs-0061R; $1: 1,500)$ from Bioss (Beijing Biosynthesis Biotechnology Co., Beijing, China), and anti-PKC- $\alpha$ (ab4124; 1:250), anti-NF- $\kappa \mathrm{B}$ (ab16502; 1:1,000), anti-TGF- $\beta 1$ (ab92486; 1:1,000), anti-TF (ab104513; 1:1,000), anti-PAI-1 (ab66705; 1:1,000), anti-PAR-1 (ab75607; 1:500) from Abcam (Cambridge, UK). All antibodies were diluted with $20 \%$ skimmed milk powder.

Statistical analysis. Statistical analysis was performed using SPSS 17.0 software (SPSS, Inc., Chicago, IL, USA), and the corresponding results are presented as the mean \pm standard deviation. Differences within groups were compared using Student's t-test, and among groups with one-way analysis of variance. $\mathrm{P}<0.05$ was considered to indicate a statistically significant difference.

\section{Results}

Effect of treatment on cell morphology of VECs. VECs from the normal control group demonstrated a round, spindle or polygonal shape with abundant and regularly arranged microvilli on the cell surface, an intact cell membrane, small intercellular space and visible cell connections. Compared with the normal group, VECs from the TNF- $\alpha$ group presented an increased cell volume and a less-regular shape, with irregularly distributed, stiff and broken microvilli. In addition, the number of cells within a single field at the same magnification was markedly greater. Compared with the TNF- $\alpha$ group, VECs from all treated groups displayed a marked improvement in cell morphology, cell size and the number and distribution of microvilli, and the number of cells in the field of view decreased (Fig. 1).

Effect of treatment on mRNA expression of $N F-\kappa B, T G F-\beta 1, T F$, $P A R-1, P K C-\alpha$ and PAI-1 in VECs. Compared with the normal group, mRNA expression of NF- $\kappa \mathrm{B}$, TGF- $\beta 1$, TF, PAR-1 and PKC- $\alpha$ genes were significantly upregulated $(\mathrm{P}<0.05)$ in the TNF- $\alpha$-induced inflammatory VECs, indicating that expression of NF- $\kappa \mathrm{B}, \mathrm{TGF}-\beta 1, \mathrm{TF}, \mathrm{PAR}-1$ and PKC- $\alpha$ was increased following TNF- $\alpha$ stimulation. Interventions using either RTA or sinapine thiocyanate alone, or a combined treatment significantly inhibited mRNA expression of TGF- $\beta 1$ and NF- $\kappa \mathrm{B}$ (both $\mathrm{P}<0.05$ ) and markedly downregulated mRNA expression of TF, PAR-1 and PKC- $\alpha$ in TNF- $\alpha$-induced inflammatory VECs; however, no significant differences were observed between these groups.

Meanwhile, PAI-1 mRNA expression was also found to be upregulated in the TNF- $\alpha$-induced inflammatory VEC model $(\mathrm{P}<0.05)$ and was positively correlated with the activity of TGF- $\beta 1$. PAI- 1 mRNA expression was significantly downregulated in VECs treated either with RTA alone or RTA and sinapine thiocyanate (both $\mathrm{P}<0.05$ ) and markedly downregulated in VECs treated with sinopine thiocyanate alone compared with the TNF- $\alpha$ group (Table I and Fig. 2).

Effect of treatment on protein expression of $N F-\kappa B, T G F-\beta 1$, TF, PAR-1, PKC- $\alpha$, and PAI-1 in VECs from each group. Compared with the TNF- $\alpha$ group, protein expression of TGF- $\beta 1$, TF, PAR-1, PAI- 1 and PKC- $\alpha$ were all significantly decreased in the normal control and DMSO groups $(\mathrm{P}<0.05)$. However, protein expression of NF- $\kappa \mathrm{B}$, TGF- $\beta 1$, TF, PAR-1, PAI-1 and PKC- $\alpha$ were all significantly decreased in VECs treated with RTA, sinapine thiocyanate, and RTA and sinapine thiocyanate as compared with that in TNF- $\alpha$-treated VECs (all $\mathrm{P}<0.05)$; however no significant differences were observed between these groups (Table II and Figs. 3 and 4).

In addition, compared with the normal control group, PAI-1 protein expression was significantly upregulated in the TNF- $\alpha$ group $(\mathrm{P}<0.05)$, indicating that PAI-1 expression was increased in TNF- $\alpha$-stimulated VECs. Furthermore, PAI-1 expression was inhibited to varying degrees by treatment with RTA, sinapine thiocyanate, and RTA and sinapine thiocyanate and was significantly decreased in all three groups compared with the TNF- $\alpha$ group $(\mathrm{P}<0.05$; Table II, Figs. 3 and 4). 
Table I. Effect of treatment on relative mRNA expression of coagulation factors in vascular endothelial cells (mean \pm standard deviation, $\mathrm{n}=3$ ).

\begin{tabular}{lcccccc}
\hline Group & NF-kB & TGF- $\beta 1$ & TF & PAR-1 & PKC- $\alpha$ & PAI- 1 \\
\hline Normal control & $0.0618 \pm 0.0262^{\mathrm{a}}$ & $0.3521 \pm 0.3711^{\mathrm{a}}$ & $0.2986 \pm 0.0420^{\mathrm{a}}$ & $0.2700 \pm 0.1588^{\mathrm{a}}$ & $0.0524 \pm 0.0267^{\mathrm{a}}$ & $0.0004 \pm 0.0003^{\mathrm{a}}$ \\
DMSO & $0.5337 \pm 0.3677^{\mathrm{a}}$ & $0.2088 \pm 0.0321^{\mathrm{a}}$ & $0.6063 \pm 0.2893^{\mathrm{a}}$ & $0.1892 \pm 0.0777^{\mathrm{a}}$ & $0.3869 \pm 0.3750^{\mathrm{a}}$ & $0.0613 \pm 0.0631^{\mathrm{a}}$ \\
TNF- $\alpha$ & 1 & 1 & 1 & 1 & 1 & 1 \\
Valsartan & $0.0490 \pm 0.0365^{\mathrm{a}}$ & $0.2072 \pm 0.3335^{\mathrm{a}}$ & $0.1095 \pm 0.0584^{\mathrm{a}}$ & $0.1385 \pm 0.2230^{\mathrm{a}}$ & $0.3781 \pm 0.4786^{\mathrm{a}}$ & $0.2743 \pm 0.4708^{\mathrm{a}}$ \\
RTA & $0.3084 \pm 0.1792^{\mathrm{a}}$ & $0.1181 \pm 0.1051^{\mathrm{a}}$ & $0.7372 \pm 0.2768$ & $0.3898 \pm 0.4012^{\mathrm{a}}$ & $0.3928 \pm 0.2107^{\mathrm{a}}$ & $0.1636 \pm 0.2692^{\mathrm{a}}$ \\
$\begin{array}{l}\text { Sinapine } \\
\text { thiocyanate }\end{array}$ & $0.5776 \pm 0.3575^{\mathrm{a}}$ & $0.1753 \pm 0.023^{\mathrm{a}}$ & $0.6029 \pm 0.269^{\mathrm{a}}$ & $0.5159 \pm 0.4500$ & $0.7951 \pm 0.1763$ & $0.4625 \pm 0.6656$ \\
$\begin{array}{l}\text { Combination } \\
\text { treatment }\end{array}$ & $0.3284 \pm 0.1524^{\mathrm{a}}$ & $0.1400 \pm 0.0711^{\mathrm{a}}$ & $0.7298 \pm 0.1475$ & $0.1401 \pm 0.3906^{\mathrm{a}}$ & $0.5576 \pm 0.1811$ & $0.0983 \pm 0.1213^{\mathrm{a}}$ \\
\hline
\end{tabular}

${ }^{\mathrm{a}} \mathrm{P}<0.05$ vs. TNF- $\alpha$ group. NF- $\kappa \mathrm{B}$, nuclear factor- $\kappa \mathrm{B}$; TGF- $\beta 1$, transforming growth factor- $\beta 1$; TF, tissue factor; PAR- 1 , protease-activation receptors; PKC- $\alpha$, protein kinase C; PAI-1, plasminogen activator inhibitor; DMSO, dimethylsulfoxide; TNF- $\alpha$, tumor necrosis factor- $\alpha$; RTA, rhynchophylla total alkaloids.
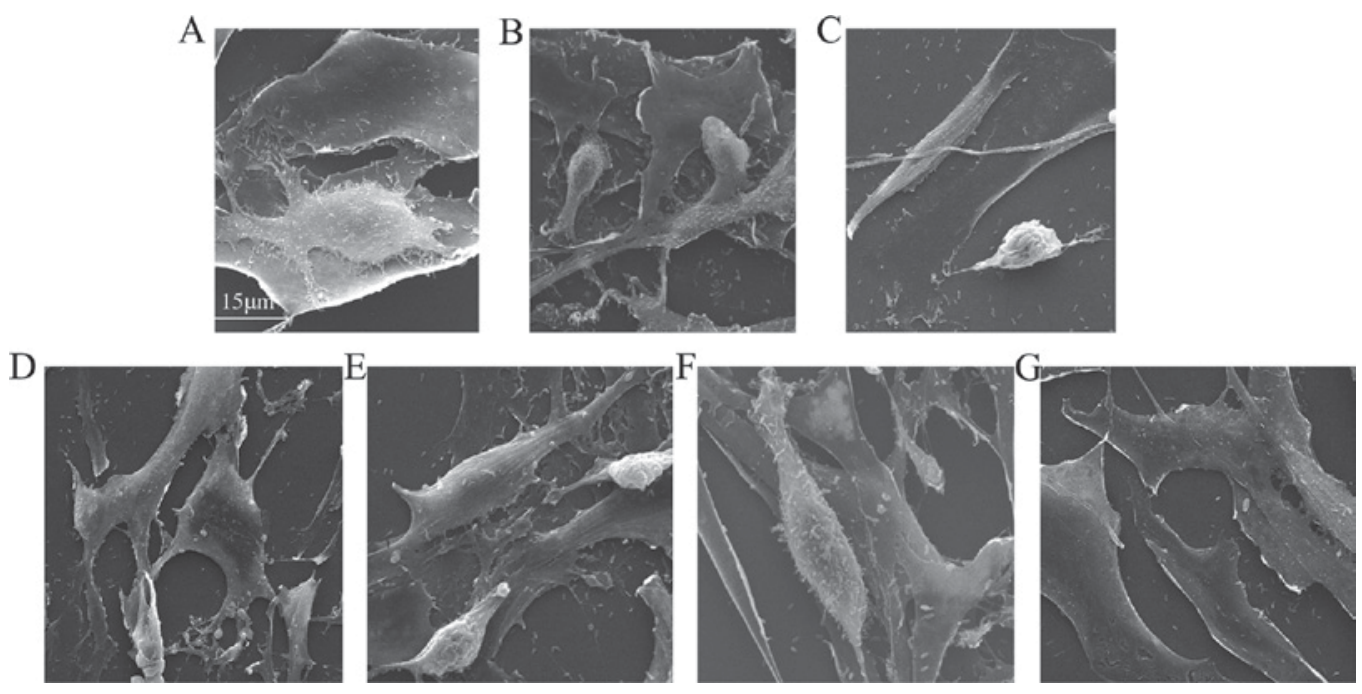

Figure 1. Morphological observation of vascular endothelial cells under scanning electron microscopy (magnification, x2,000). (A) Normal control, (B) tumor necrosis factor- $\alpha,(C)$ valsartan, (D) rhynchophylla total alkaloids (E) sinapine thiocyanate, (F) combined treatment and (G) dimethylsulfoxide groups.

\section{Discussion}

TNF- $\alpha$ is a multifunctional, proinflammatory factor, secreted by activated macrophages that can directly damage VECs. After binding to the TNF- $\alpha$ receptor on the cell membrane of VECs, TNF- $\alpha$ exerts its biological effect via multiple pathways (11-15) to induce inflammation and alter coagulant/fibrinolytic function of VECs (16), leading to inflammation and coagulation. In the present study, a TNF- $\alpha$-induced VEC injury model was established to investigate alterations in cell morphology and subcellular structures. The results demonstrated that TNF- $\alpha$ (5 $\mu \mathrm{g} / \mathrm{l})$ successfully induced in vitro vascular endothelial injury, manifested by enlarged, irregularly-shaped cells with stiff and broken microvilli, irregularly distributed on the cell surface and a markedly increased number of cells in a single field of view under SEM. Conversely, following treatment with RTA, sinapine thiocyanate or RTA and sinapine thiocyanate, the cell morphology improved to a varying extent and the number of cells in a single field of view increased. This result suggests that RTA and sinapine thiocyanate are able to antagonize TNF- $\alpha$-induced VEC damage, manifested by a marked improvement in cell size and morphology of VECs as well as the quantity and distribution of microvilli.

The procoagulant effect during inflammation is achieved via multiple pathways, initiated by TF expression. Under normal physiological conditions, VECs exhibit antithrombotic and anticoagulant function, illustrated by extremely low or almost nil expression of TF (17). TF is activated via multiple pathways. Firstly, high TF expression may be induced during TNF- $\alpha$-induced VEC injury or dysfunction (17), initiating the extrinsic coagulation pathway, leading to hemostatic imbalance and a shift towards coagulation/thrombosis. Secondly, the activation and nuclear translocation of NF- $\mathrm{KB}$ is important in TF expression. Activated by TNF- $\alpha$, NF- $\kappa B$ dimers translocate into the nucleus, bind to specific sites on the DNA, and induce and accelerate the transcription of corresponding genes, leading to TF protein expression $(18,19)$. Thirdly, TGF- $\beta 1$ released from activated platelets induces increased 
Table II. Effect of treatment on protein expression of coagulation factors in vascular endothelial cells (mean \pm standard deviation, $\mathrm{n}=3)$.

\begin{tabular}{lcccccc}
\hline Group & NF- $\mathrm{NB}$ & TGF- $\beta 1$ & TF & PAR-1 & PKC- $\alpha$ & PAI- \\
\hline Normal control & $0.2291 \pm 0.0251$ & $0.1371 \pm 0.0051^{\mathrm{a}}$ & $0.0614 \pm 0.0038^{\mathrm{a}}$ & $0.0601 \pm 0.0018^{\mathrm{a}}$ & $0.0641 \pm 0.0008^{\mathrm{a}}$ & $0.0668 \pm 0.0116^{\mathrm{a}}$ \\
DMSO & $0.2289 \pm 0.0218$ & $0.1603 \pm 0.0113^{\mathrm{a}}$ & $0.0591 \pm 0.0023^{\mathrm{a}}$ & $0.0689 \pm 0.0029^{\mathrm{a}}$ & $0.0574 \pm 0.0067^{\mathrm{a}}$ & $0.1109 \pm 0.0105^{\mathrm{a}}$ \\
TNF- $\alpha$ & $0.2574 \pm 0.0011$ & $0.3092 \pm 0.0322^{\mathrm{a}}$ & $0.0867 \pm 0.0026$ & $0.1343 \pm 0.0197$ & $0.1346 \pm 0.0085$ & $0.1833 \pm 0.0186$ \\
Valsartan & $0.1514 \pm 0.0321^{\mathrm{a}}$ & $0.1570 \pm 0.0135^{\mathrm{a}}$ & $0.0554 \pm 0.0053^{\mathrm{a}}$ & $0.0813 \pm 0.0015^{\mathrm{a}}$ & $0.0982 \pm 0.0165^{\mathrm{a}}$ & $0.1335 \pm 0.0139^{\mathrm{a}}$ \\
RTA & $0.1774 \pm 0.0107^{\mathrm{a}}$ & $0.1516 \pm 0.0257^{\mathrm{a}}$ & $0.0665 \pm 0.0042^{\mathrm{a}}$ & $0.0562 \pm 0.0044^{\mathrm{a}}$ & $0.0561 \pm 0.0038^{\mathrm{a}}$ & $0.1344 \pm 0.0045^{\mathrm{a}}$ \\
Sinapine & $0.1900 \pm 0.0120^{\mathrm{a}}$ & $0.1352 \pm 0.0143^{\mathrm{a}}$ & $0.0759 \pm 0.0029^{\mathrm{a}}$ & $0.0889 \pm 0.0168^{\mathrm{a}}$ & $0.1107 \pm 0.0118^{\mathrm{a}}$ & $0.1078 \pm 0.0211^{\mathrm{a}}$ \\
thiocyanate & & & & & & \\
Combination & $0.1682 \pm 0.0348^{\mathrm{a}}$ & $0.1852 \pm 0.0025^{\mathrm{a}}$ & $0.0680 \pm 0.0005^{\mathrm{a}}$ & $0.0760 \pm 0.0067^{\mathrm{a}}$ & $0.0796 \pm 0.0013^{\mathrm{a}}$ & $0.1569 \pm 0.0174^{\mathrm{a}}$ \\
treatment & & & & & & \\
\hline
\end{tabular}

${ }^{a} \mathrm{P}>0.05$ vs. TNF- $\alpha$ group. NF- $-\mathrm{B}$, nuclear factor- $\kappa \mathrm{B}$; TGF- $\beta 1$, transforming growth factor $-\beta 1$; TF, tissue factor; PAR- 1 , protease-activation receptors; PKC- $\alpha$, protein kinase C; PAI-1, plasminogen activator inhibitor; DMSO, dimethylsulfoxide; TNF- $\alpha$, tumor necrosis factor- $\alpha$; RTA, rhynchophylla total alkaloid.
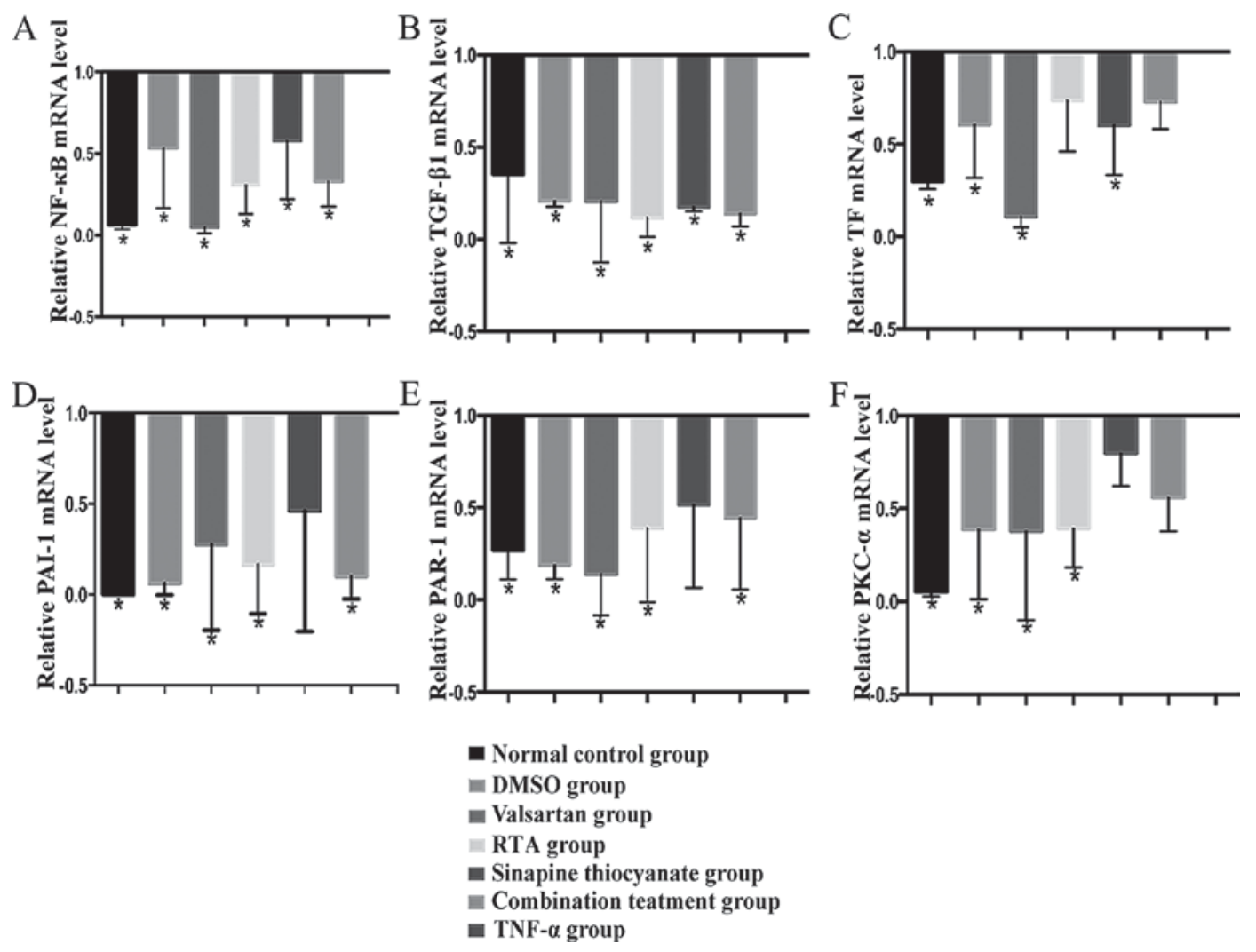

Figure 2. mRNA expressions profiling of coagulation factors in VECs. Reverse transcription-quantitative polymerase chain reaction expression of inflammation and coagulation factors (A) NF-kB, (B) TGF- $\beta 1$, (C) TF, (D) PAI-1, (E) PAR-1 and (F) PKC- $\alpha$ in TNF- $\alpha$-mediated VSCs following treatment with different agents. Data are presented as mean \pm standard deviation, $n=3$ per group. ${ }^{*} \mathrm{P}<0.05$ vs. TNF- $\alpha$ group. VECs, vascular endothelial cells; NF- $\mathrm{kB}$, nuclear factor- $\mathrm{kB}$; TGF- $\beta 1$, transforming growth factor- $\beta 1$; TF, tissue factor; PAR-1, protease-activation receptors; PAI-1, plasminogen activator inhibitor; PKC- $\alpha$, protein kinase C; TNF- $\alpha$, tumor necrosis factor- $\alpha$; DMSO, dimethylsulfoxide; RTA, rhynchophylla total alkaloids.

TF expression in human umbilical vein endothelial cells (20). TGF- $\beta 1$ is a major factor regulating TF expression in VECs via the $\mathrm{NF}-\kappa \mathrm{B} / \mathrm{TGF}-\beta 1 / \mathrm{SMADs}$ signaling pathway (21). TGF- $\beta 1$ released from activated platelets is able to enhance the procoagulant activity in vascular endothelium by promoting TF generation by VECs. The underlying mechanisms may include increased TF expression via increased TGF- $\beta 1$ production and
MAPK activation $(22,23)$. The present study demonstrates that $\mathrm{TNF}-\alpha$ stimulation may result in enhanced expression of TGF- $\beta 1, N F-\kappa B$ and TF in VECs and initiate the extrinsic coagulation pathway. In addition, the combined use of RTA and sinapine thiocyanate may inhibit the protein and mRNA expression of TF, TGF- $\beta 1$ and $N F-\kappa B$ in a TNF- $\alpha$-induced inflammatory VEC model, indicating that treatment with RTA 

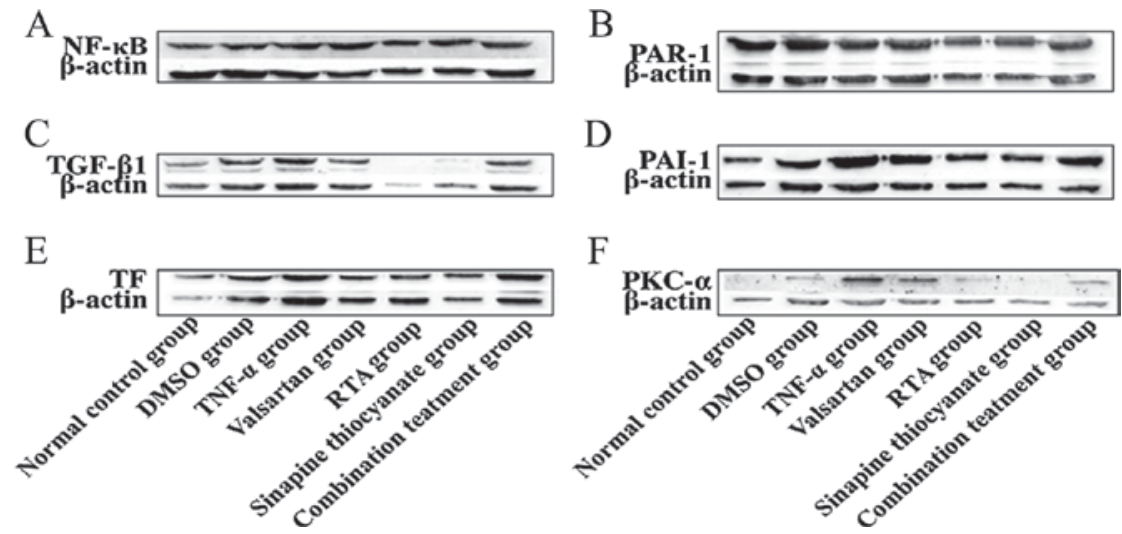

Figure 3. Western blots of inflammation and coagulation factors (A) NF- $\mathrm{kB}$, (B) PAR-1, (C) TGF- $\beta 1$, (D) PAI-1, (E) TF and (F) PKC- $\alpha$ in TNF- $\alpha$ mediated vascular endothelial cells. Seven lanes indicate the following groups, respectively: Normal control, DMSO, TNF- $\alpha$, valsartan, RTA, sinapine thiocyanate and

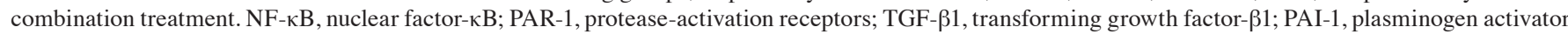
inhibitor; TF, tissue factor; PKC- $\alpha$, protein kinase C; TNF- $\alpha$, tumor necrosis factor- $\alpha$; DMSO, dimethylsulfoxide; RTA, rhynchophylla total alkaloids

\section{A}

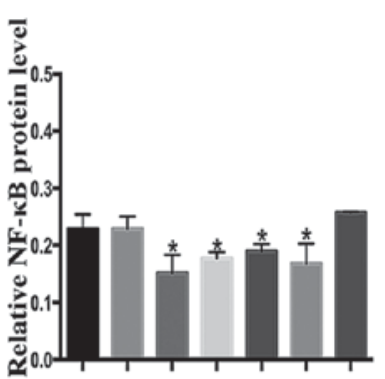

$\mathrm{B} \overline{\mathrm{D}}$
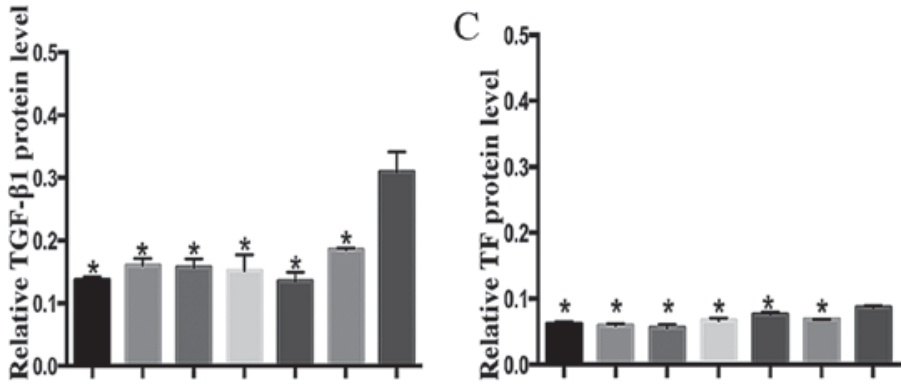

D
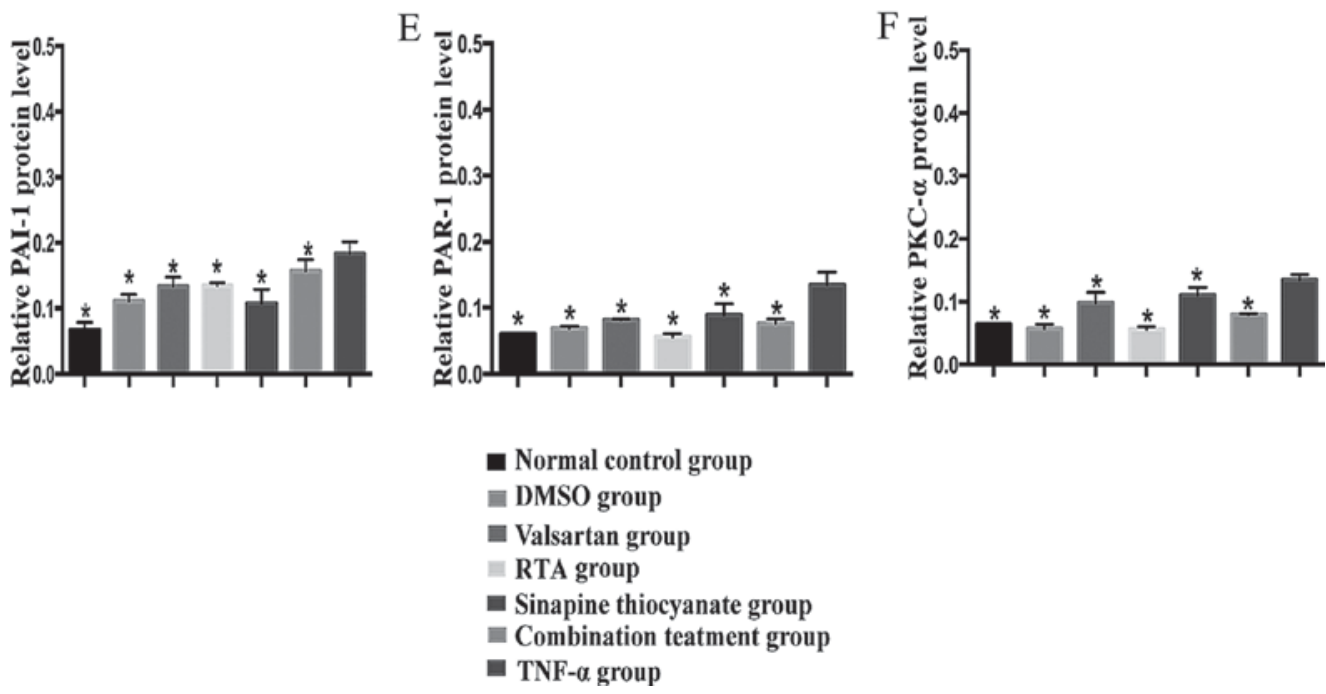

Figure 4. Western blot analysis of coagulation factors in VECs. Western blot analyzed protein level of inflammation and coagulation factors (A) NF-кB (B) TGF- $\beta 1$, (C) TF, (D) PAI-1, (E) PAR-1 and (F) PKC- $\alpha$ in TNF- $\alpha$-mediated VECs following treatment with different agents. Data are presented as mean \pm standard deviation, $n=3$ per group. ${ }^{*} \mathrm{P}<0.05$ vs. TNF- $\alpha$ group. VECs, vascular endothelial cells; NF- $\mathrm{k}$, nuclear factor- $\mathrm{kB}$; TGF- $\beta 1$, transforming growth factor- $\beta 1$; TF, tissue factor; PAR-1, protease-activation receptors; PAI-1, plasminogen activator inhibitor; PKC- $\alpha$, protein kinase C; TNF- $\alpha$, tumor necrosis factor- $\alpha$; DMSO, dimethylsulfoxide; RTA, rhynchophylla total alkaloids.

and sinapine thiocyanate directly reduces TF expression and indirectly inhibits TF expression by reducing TGF- $\beta 1$ and NF- $\kappa \mathrm{B}$ expression.

Following the initiation of the extrinsic coagulation pathway, TF enhances thrombin expression and binds to PAR on the cell surface. This activates the receptor-G protein-PLC-DG-PKC signaling pathway, which leads to increased expression and the development of coagulation during inflammation. Mediated by signal transduction via Gq proteins, PAR-1 activates phospholipase $\mathrm{C}$, which decomposes phospholipids and generates IP3. In turn, this triggers $\mathrm{Ca}^{2+}$ release from the endoplasmic reticulum, resulting in an increased concentration of cytosolic $\mathrm{Ca}^{2+}$ and further activation of PKC $(24,25)$. PKC is one of the most important molecules involved in post-membrane signaling transduction and participates in a crucial cell-signaling transduction pathway for atherosclerosis (26). 
The results from the present study demonstrate that mRNA and protein expression of PAR-1 and PKC- $\alpha$ is positively correlated with that of TF, TGF- $\beta 1$ and $\mathrm{NF}-\kappa \mathrm{B}$, indicating that the receptor-G protein-PLC-DG-PKC signaling pathway is activated following the initiation of the extrinsic coagulation pathway. In the present study, treatment with RTA and sinapine thiocyanate downregulated the protein and mRNA expression of PAR-1 and PKC- $\alpha$, which suggests that the combined use of RTA and sinapine thiocyanate may further suppress the activation of the receptor-G protein-PLC-DG-PKC signaling pathway, thereby reducing the expression of blood coagulation factors during inflammation and inhibiting the procoagulant state of the vascular endothelium.

Furthermore, TGF- $\beta 1$ upregulates PAI-1 expression at the transcriptional level via the TGF- $\beta 1 /$ SMADs and TGF- $\beta 1 /$ MAPK signaling pathways $(27,28)$. PAI is a serine protease inhibitor. Activated PAI, at physiological concentrations, inactivates tissue-type plasminogen activator (t-PA) by forming a 1:1 complex with t-PA, thereby balancing fibrinolytic activity (29). Decline in fibrinolytic activity is likely to be a critical risk factor for a variety of cardiovascular and cerebrovascular events. In addition, t-PA in the arterial wall activates plasminogen to plasmin, which in turn leads to the degradation of the extracellular matrix and fibrin deposited in the arterial intima (30). Under normal circumstances, there is a dynamic balance between plasmin and thrombin. However, when the vascular endothelium is injured, PAI-1 expression increases and leads to t-PA inactivation by binding to t-PA, leading to a decrease in plasmin concentration and a relative increase of thrombin expression (29). In addition, increased deposition of extracellular matrix and fibrin in the arterial wall might be a potential cause for vascular endothelial injury because this further promotes VEC injury and proliferation of smooth muscle cells.

The results of the present study demonstrated that PAI-1 activity is positively correlated with that of TGF- $\beta 1$. Compared with the model group, mRNA and protein expression of TGF- $\beta 1$ and PAI- 1 in all the treatment groups was downregulated to varying extents. This result confirmed that the combined treatment with RTA and sinapine thiocyanate inhibits the TGF- $\beta 1$ signaling pathway and thereby downregulates PAI-1 expression, which may help with restoring the dynamic balance between plasmin and thrombin and reduce fibrin deposition on endothelial cells, thereby inhibiting the procoagulant state in the vascular endothelium.

In addition to phenotypical alterations in the vascular endothelium causing a shift from the anti-inflammatory and anti-coagulant to pro-inflammatory and pro-coagulant state, the role of the vascular endothelium in the maintenance of vascular homeostasis is gradually inhibited, which becomes an initiating factor and mediator for the endothelium-hypertension-cardiovascular events cascade. Therefore, reversing the prothrombosis state of the vascular endothelium is particularly important. The present study demonstrates that combined treatment with RTA and sinapine thiocyanate is able to downregulate the expression of coagulation-related factors during VEC injury, thus inhibiting the shift from anticoagulant and antithrombotic state to procoagulant and PTS. In addition, the underlying mechanism is partially associated with TF-mediated activation of the thrombin-receptor signaling pathway that suppresses coagulation during inflammation and balances fibrinolysis to inhibit fibrin generation and deposition.

\section{Acknowledgements}

The present study was funded by the Natural Science Foundation of China (grant no. 81273700).

\section{References}

1. Lip GH: Target organ damage and the prothombotic state in hypertension. Hypertension 6: 975-977, 2000.

2. Xu Y, Gong B, Yang Y, Awasthi $\mathrm{YC}$ and Boor PJ: Adenovirus-mediated overexpression of glutathione-s-transferase mitigates transolant arteriosclerosis in rabbit carotid allografts. Transplantation 89: 409-416, 2010.

3. Vu TK, Hung DT, Wheaton VI and Coughlin SR: Molecular cloning of a functional thrombin receptor reveals a novel proteolytic mechanism of receptor activation. Cell 64: 1057-1068, 1991.

4. Shin SC and Lee DU: Ameliorating effect of new constituents from the hooks of Uncaria rhynchophylla on scopolamine-induced memory impairment. Chin J Nat Med 11: 391-395, 2013.

5. Jiang YH, Li YL, Zhao J and Hud Q: Uncaria alkaloids' intervention on the aged endothelial cell induced by D-galactose. Chin J Arteriosclerosis 19: 474-478, 2011

6. Sun JC, Qi DM, Zhou HL and Li YL: The influence of gouteng alkaloid on SHR aorta smooth muscle cell apoptosis and proliferation. Chin Pharmacol Bulletin 27: 925-929, 2011.

7. Yang JG, Li YL and Zhou HL: Protective effect of total alkaloids from Uncariae Ramulus cum uncis combined with Raphani Semen on vascular endothelial cell injury by hypertension. Chin Tradit Patent Med 35: 15-19, 2013.

8. Liu L, Zhao SP, Zhou HN, Li QZ and Li JX: Effect of fluvastatin and valsartan, alone and in combination, on postprandial vascular inflammation and fibrinolytic activity in patients with essential hypertension. J Cardiovasc Pharmacol 50: 50-55, 2007.

9. Jiao HC, Li YL, Jiang YH, Qi DM, Han T and Jiang HQ: Effect and mechanism of total alkaloids of rhynchophylla rhynchophylla and sinapine thiocyanate on vascular endothelial cells Chin J Arteriosclerosis 21: 397-403, 2013.

10. Livak KJ and Schmittgen TD: Analysis of relative gene expression data using real-time quantitative PCR and the 2(-Delta Delta C(T)) Method. Methods 25: 402-408, 2001.

11. Keiser SD, Veillon EW, Parrish MR, Bennett W, Cockrell K, Fournier L, Granger JP, Martin JN Jr and Lamarca B: Effects of 17-hydrixyprogesterone on tumor necrosis factor-alpha-induced hypertension during pregnancy. Am J Hypertens 22: 1120-1125, 2009.

12. Goodwin BL, Pendleton LC, Levy MM, Solomonson LP and Eichler DC: Tumor necrosis factor-alpha reduced argininosuccinate synthase expression and nitric oxide production in aortic endothelial eclls. Am J Physiol Heart Circ Physiol 293: H1115-H1121, 2007.

13. Xia Z, Liu M, Wu Y, Sharma V, Luo T, Ouyang J and McNeill JH: $\mathrm{N}$-acetylcysteine attenuates TNF-alpha-induce human vascular endothelial cell apoptosis and restires eNOS expression. Eur J Pharmacol 550: 134-142, 2006.

14. Seidel M, Billert $H$ and Kurpisz M: Regulation of eNOS expression in HCAEC cell line treated with opioids and proinflammatory cutokines. Kardiol Pol 64: 153-160, 2006.

15. Gao X, Belmadani S, Picchi A, Xu X, Potter BJ, Tewari-Singh N, Capobianco S, Chilian WM and Zhang C: Tumor necrosis factor-alpha induces endothelial dysfunction in Lepr(db) mice. Circulation 115: 245-254, 2007.

16. Grau GE, de Moerloose P, Bulla O, Lou J, Lei Z, Reber G, Mili N, Ricou B, Morel DR and Suter PM: Hemostatic properties of human pulmonary and cerebral microvascular endothelial cells. Thromb Haemost 77: 585-590, 1997.

17. Cheng CY, Sun Y, Wen ZB, He XF, Wang GF, Un GQ, Jiang HH, Tian XM and He SL: Mechanisms for tetramethylpyrazine on the expression of tissue factor induced by thrombin in vascular endothelial cells. Chin J Arteriosclerosis 18: 184-188, 2010.

18. Butenas S, Bouchard BA, Brummel-Ziedins KE, Parhami-Seren B and Mann KG: Tissue factor activity in whole blood. Blood 105: 2764-2770, 2005. 
19. Morgan MJ and Liu ZG: Crosstalk of reactive oxygen species and NF- $\kappa$ B signaling. Cell Res 21: 103-115, 2011.

20. Pihusch V, Pihusch M, Penovici M, Kolb HJ, Hiller E and Pihusch R: Transforming growth factor beta-1 released from platelets contributes to hypercoagulability in veno-occlusive disease following hematopoetic stem cell transplantation. Thromb Res 116: 233-240, 2005.

21. Tieri P, Termanini A, Bellavista E, Salvioli S, Capri M and Franceschi C: Charting the NF- $\kappa \mathrm{B}$ pathway interactome map. PLoS One 7: e32678, 2012.

22. Vega-Ostertag M, Casper K, Swerlick R, Ferrara D, Harris EN and Pierangeli SS: Involvement of p38 MAPA in up-regulation of tissue factor on endothelial cells by antipholipid antibodies. Arthritis Rheum 52: 1545-1554, 2005.

23. Shifera AS: The zinc finger domain of ikk $\gamma$ (NEMO) protein in health and disease. J Cell Mol Med 14: 2404-2414, 2010.

24. Suzuki A and Ohno S: The PAR-aPKC system: Lessons in polarity. J Cell Sci 119: 979-987, 2006.

25. Wang $\mathrm{H}$ and Reiser $\mathrm{G}$. The role of the $\mathrm{Ca} 2+$-sensitive tyrosine kinase Pyk 2 and Src in thrombin signalling in rat astrocytes. J Neurochem 84: 1349-1357, 2003.
26. Pereira FE, Coffin JD and Beall HD: Activation of protein kinase $\mathrm{C}$ and disruption of endothelial monolayer integrity by sodium arsenite-Potential mechanism in the development of atherosclerosis. Toxicol Appl Pharmacol 220: 164-177, 2007.

27. Saura M, Zaragoza C, Herranz B, Griera M, Diez-Marqués L, Rodriguez-Puyol D and Rodriguez-Puyol M: Nitric oxide regulates transforming growth factor-beta signaling in endothelial cells. Circ Res 97: 1115-1123, 2005.

28. Guo B, Inoki K, Isono M, Mori H, Kanasaki K, Sugimoto T, AkibaS, Sato T, Yang B,Kikkawa R, etal: MARK/AP-1-dependent regulation of PAI-1 gene expression by TGF-beta in rat mesangial cells. Kident Int 68: 972-984, 2005.

29. Yasar Yildiz S, Kuru P, Toksoy Oner E and Agirbasli M Functional stability of plasminogen activator inhibitor-1. ScientificWorld Journal 2014: 858293, 2014.

30. Kruithof EK and Dunoyer-Geindre S: Human tissue-type plasminogen activator. Thromb Haemost 112: 243-254, 2014. 